\title{
HISTOMORPHOLOGAL AND HISTOCHEMICAL STRUCTURE IN THE DUODENUM OF SHEEP (Ovis aries) AND RABBIT (Oryctolagus cuniculus); A COMPARATIVE STUDY
}

\author{
Hawraa Jabbar MOHAMMAD ${ }^{1}$, Ali Khalaf ALI ${ }^{1 \times 凶}$, Zainab Abdul Jabbar Ridha AL-ALI ${ }^{1}$ \\ ${ }^{1}$ Department of Biology, College of Science, University of Misan, Maysan, Iraq \\ Email: Dr.Alikhalaf@uomisan.edu.iq; (1) ORCiD: 0000-0003-2273-6433 \\ Supporting Information
}

ABSTRACT: This study aimed to compare the histomorphometric and histochemical features of the duodenum twenty sheep $(n=10)$ and rabbit $(n=10)$ adult males. The samples were collected from slaughterhouse and markets of Misan and were used for histological studies of two types of stains, hematoxylin and eosin, and special stains (Periodic acid Schiff stains). In histological approach, in both animals, the wall of the duodenum consists of four layers (mucosa, submucosa, muscularis and serosa). In both animals, the mucosa of the duodenum lined by simple columnar epithelium and has number of villi compose of absorptive (enterocytes) and goblet cells only in duodenum, the submucosa occupied by Brunner's glands. Brunner's glands are varying in secretory unit acinai in rabbit serous and mucous acini while in sheep the mucus acini. There is significant difference in thickness of layers between sheep and rabbits. Mucosa, sub mucosa and muscularis layers in sheep showed more thickness than in rabbits, but there is non- significant $(P>0.05)$ differences between the thickness of the serosa in sheep and rabbit in the duodenum. On the other hand, the columnar cells showed a weakly reaction with Periodic acid Schiff stain (PAS), but goblet cells in sheep and rabbits shown strong reaction with PAS. While the Brunner's glands were strong reaction with PAS in sheep and weakly reaction with PAS in rabbit. In conclusion, this study showed that sheep and rabbits have similarities and differences in the duodenum; that is, the layers of this organ has different thicknesses and respond differently to periodic acid Schiff stain.

Keywords: Duodenum, Histochemistry, Histomorphology, Rabbit, Sheep

\section{INTRODUCTION}

Evolution between animals causes many changes so that it can adapt to its environments. Each animal species has unique characters that help them survive and can consume different types of feed (Salama et al., 2019). Rabbits are considered economically significant animals as they have the advantage of their meat and furring, are used as pets, and they are substantial at scientific and medical experiences (Salama et al., 2019). On the other hand, sheep have been able to use lignocellulosic materials and convert them to animal products of high nutritional value, such as meat, milk, wool/fur, hide, and manure (Saeed et al., 2018). Fermentation organs are depend on a symbiotic relationship with a community of microbes, primarily bacteria with fibrinolytic ability in either their foregut (which the rumen of ruminants and the pseudo-ruminants) or their hindgut (which the cecum and colon of non-ruminant herbivores), for fiber digestion (Crowley et al., 2017; Kingston-Smith et al., 2012).

Given the comparative investigations of the digestive tract it can be said that the level of development of each segment is directly related to the living environment, nutritional and metabolic needs (Kotze et al., 2010). The small intestine is a long, tubular organ, connects the stomach to the large intestine and can be divided into duodenum, Jejunum and lleum based on anatomy and function, the duodenum is a tiny fraction of the small intestine, it is the site of most of the breakdown of the food passing through it, the duodenum is line with duodenal sub mucosal glands, which secrete an alkaline mucus that supports the intestinal enzymes and aids in the absorption of nutrients (Cunningham and Klein, 2007). In histological approach, the duodenum wall has four concentric layers: mucosa, submucosa, muscularis and serosa, and this structure have also been observed in other mammalian species (Gadelha-Alves et al., 2008). The surface epithelium of small intestine is covers by the villi which are already protruded into the intestinal lumen and it also lines the crypts which are extended to the connective tissue (Mohamed et al., 2019). Kadadi (2012) descripted that the villi are finger like projections forms of a core of reticular tissue covers by surface epithelium, Also, among the villi are small openings of the simple tube glands called the intestinal glands (crypts of Lieberkuhn). Whereas, Al-Shamary et al. (2017) stated that the crypts of Lieberkühn are simple tubular glands called intestinal glands that were extend from the muscularis mucosa till the bases of the villi, they were lined by a simple columnar epithelium. Calamar et al. (2014) reported that the sub-mucosa tunic is formed of loose connective tissue and provides support for the vascular and nerve network. The Brunner's glands: are branched tubuloalveolar glands, located in sub mucosa, they existed at each 
mammalian species (AL-Baghdady et al., 2012). The muscularis layer of small intestine composes of two layers of smooth muscle cells internal-circular and external-longitudinal (Calamar et al., 2014). The intestine has no serosa, the layer external to the tunica muscularis would be referred to as the adventitia (Nzalak, 2010).

This study aimed to compare the histomorphometric and histochemical similarities of the duodenum of sheep (herbivorous ruminant) and rabbit (herbivorous and coprophagous).

\section{MATERIALS AND METHODS}

\section{Surgical procedures}

The present study was carried out in the department of biology Sciences at the University of Misan. A total of ten sheep, adult males, were collected from local slaughterhouses and ten rabbits, were weight of $1.5-2.5 \mathrm{~kg}$ and their age is almost three months adult males, were collected from Misan city. The experiments on rabbits followed the guidelines provided by the University's Animal Ethics Committee. The rabbits were raised under standard procedures and euthanized following the animal euthanization protocol. A physical examination was performed to all animals to guarantee they were all in the right health conditions before the euthanasia. The euthanizing procedures were done by placing $2 \mathrm{~mL}$ of chloroform $(\mathrm{CHCl} 3)$ on cotton and then set on the animal's nose, according to Blackshaw et al. (1988). By using appropriate tools as scissors, tweezers and scalpels regional gross dissection was performed of each specimen. The abdomen of the rabbits was incised, and the duodenum extracted. Then, taken $1 \mathrm{~cm}$ from duodenum.

\section{Histological examination}

All duodenum samples of rabbits and sheep were fixed in $10 \%$ neutral buffered formalin promptly. After fixation for 72 hours, all samples were processed with a series of ascending ethanol concentrations $(70 \%, 2 \mathrm{~h} .80 \%, 30 \mathrm{~min} .96 \%$, three changes, $2 \mathrm{~h}$ each. $100 \%$ abslute, $9 \mathrm{~h}$ than $100 \%$ hour) to dehydrate them. Then, all samples were cleared with xylene for one hour and embedded in paraffin wax to make paraffin blocks. Finally, sections were cut at 7-micrometer thickness and processed with two stains (Luna, 1968). Hematoxylin and Eosin and Periodic Acid-Schiff (PAS) stains were used to stain all tissue sections for histomorphometry identification and carbohydrates determinations, respectively (Luna, 1968).

\section{Micromorphometric measurements}

Ten slides were made duodenum, and to detect the thickness of mucosa, submucosa, muscular, and serosa, we followed the literature methods which by using the optical microscope with the exact ophthalmic scale (ocular micrometer) after the exact ophthalmic scale was matched with the theatrical scale using the magnification force (Galigher and Kozloff, 1964).

\section{Statistical analysis}

The values were expressed as mean \pm SD (standard deviation). The statistical analysis of the data was performed to know the significant differences using t-test at $P<0.05$ of probability (Al-Rawi and Khalaf Allah, 2000).

\section{RESULTS and DISCUSSION}

\section{Histological study}

Histological examination results show that the mucosa of duodenum has number of villi compose of absorptive (enterocytes) and goblet cells only (Figures 1 and 2). The columnar cells have nucleus round found in near the base, and cytoplasm was eosinophilic, while goblet cells are unicellular in its apical part becomes puffy due to mucigen droplets accumulation and have nucleus is irregularly oval or triangular at the base and in both species have same characteristic, and cytoplasm seen clear post staining with hematoxylin and eosin stain. These results are similar to the study of Parveen et al. (2013). However, the stem cells give rise to 4 major epithelial cells: the absorptive enterocytes which make up about $80 \%$ fall small intestinal epithelial cells; the goblet cells which produces a variety of mucins and trefoil peptides needed for epithelial growth and repair; the enteroendocrine cells which export peptide hormones; and the paneth cells which secretes antimicrobial cryptdins or defensins, digestive enzymes, and growth factors (Korkmaz and Kum, 2016). Ergun et al. (2003) stated that absence paneth cells in the villi of small intestine and that these cells were differentiated as such toward the base of the crypts. Lamina propria: in both animals consist from loose connective tissue containing blood vessel, nerves, lymphatic assembles, and the intestinal glands or called crypts of lieberkuhn extended to below mascularis mucosa and consists of the columnar cells, the goblet cells and the Paneth's cells (Figures 5 and 6 ), these glands well developed appeared simple tubular and this finding similarity with (Hassan and Moussa, 2015). Mascolaris mucosa composed of smooth muscle fiber, it located at the base of the crypt is thin in rabbit but it thicker and very clear in sheep. Muscularis mucosa thin layer of circular smooth muscle fibers at the blow of the crypt but seen more thickness in sheep consistent with Lesson and Lesson (1988). Submucosa layer seen as a thin layer of loose connective tissue abundantly supplied by blood vessels, lymphocytes, collagen and elastic fiber, it locate below mucosa layer, in the duodenum contains glands called (Brunner's glands), Brunner's glands are developed very increased in density in the sub 
mucosa of the duodenum sheep than in rabbit, these are simple tubular. Brunner's glands are vary in secretory unit acinai in rabbit serous and mucous acini where characterized by their relatively wide lumen and their cells appeared pale, while in sheep the mucus acini. In both animals sub mucosa only in the duodenum has Brunner's glands are simple tubular. The duodenum is the site of most of the breakdown of the food passing through it (Elnasharty et al., 2013). Brunner's glands have function neutralizes chyme entering to the duodenum from the pylorus, protecting the mucous membrane, and bringing the intestinal contents to the optimum pH for pancreatic enzyme action (Emel et al., 2010). Hassan and Moussa (2015) reported that duodenum goat didn't exhibit any glands of Brunner at the sub mucosa layer nor did the sub mucosa of jejunum contain any glands or lymphoid nodules. The muscularis layer composed by an inner circular and an outer longitudinal layer of smooth muscles and between connective tissue, similar findings were reported in sheep (Kumar et al., 2015). The serosa layer formed by the loose connective tissue had collagen, elastic and also reticular fibers along with varying amounts of fatty tissue, few blood capillaries, and flat mesothelial cells layer as reported in domestic animals (Stinson and Calhoun, 1993).

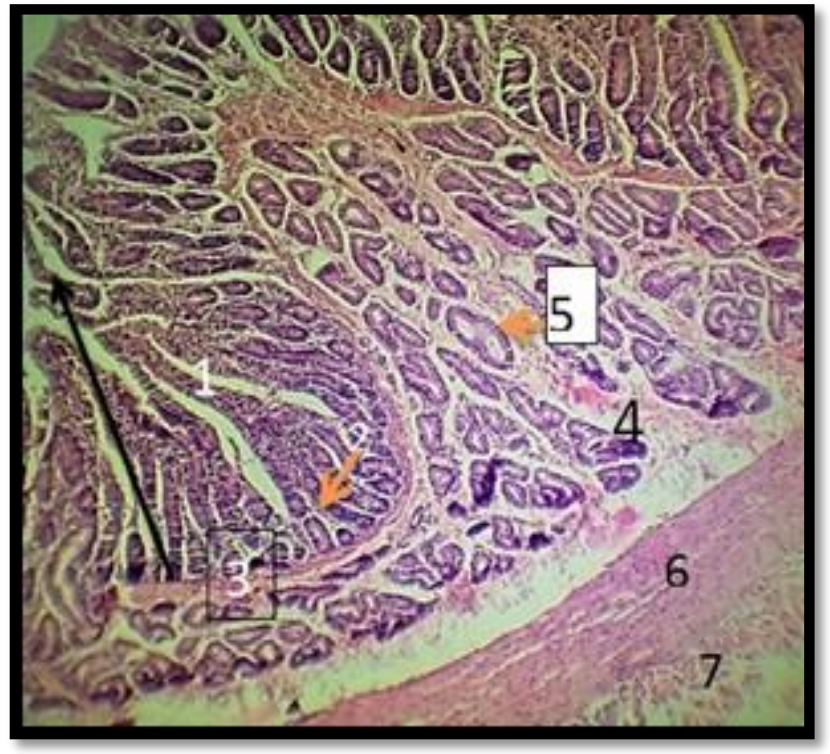

Figure 1 - The duodenum of the sheep showing mucosa, contain villi (1) gland (crypt) of Liebrkuhn (2). muscolaris mucosa (3). Submucosa (4) Brunner's glands (5). muscularis (6) serosa(7). H\&E.100X

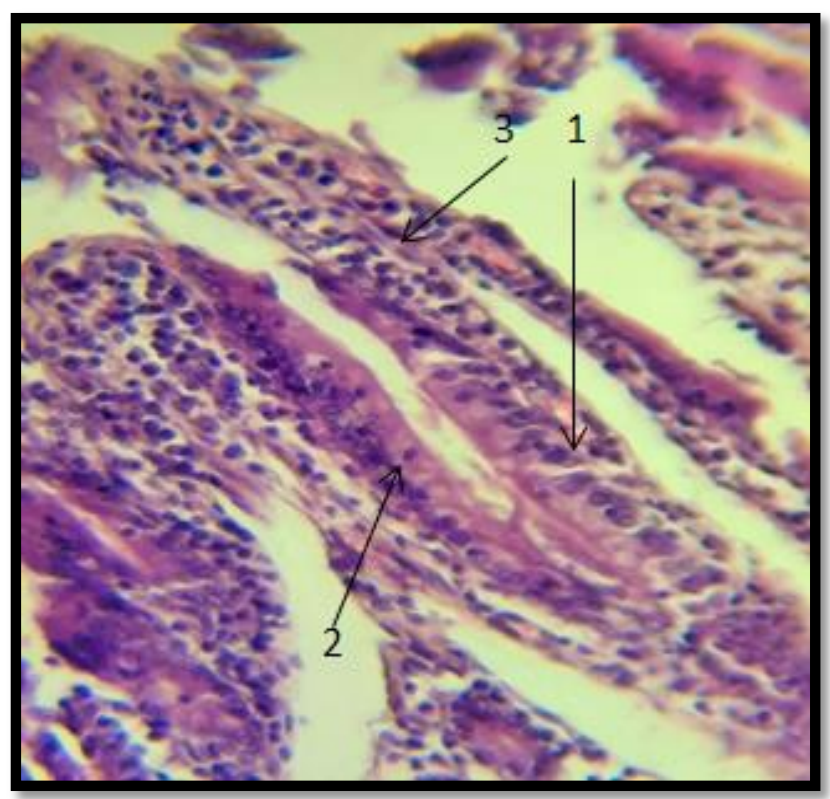

Figure 3 - The villi of the sheep in doudenum consist of enterocytes (1), goblet cells (2), (lacteal) (3) of villi consist of loose connective tissue H\&E.100X

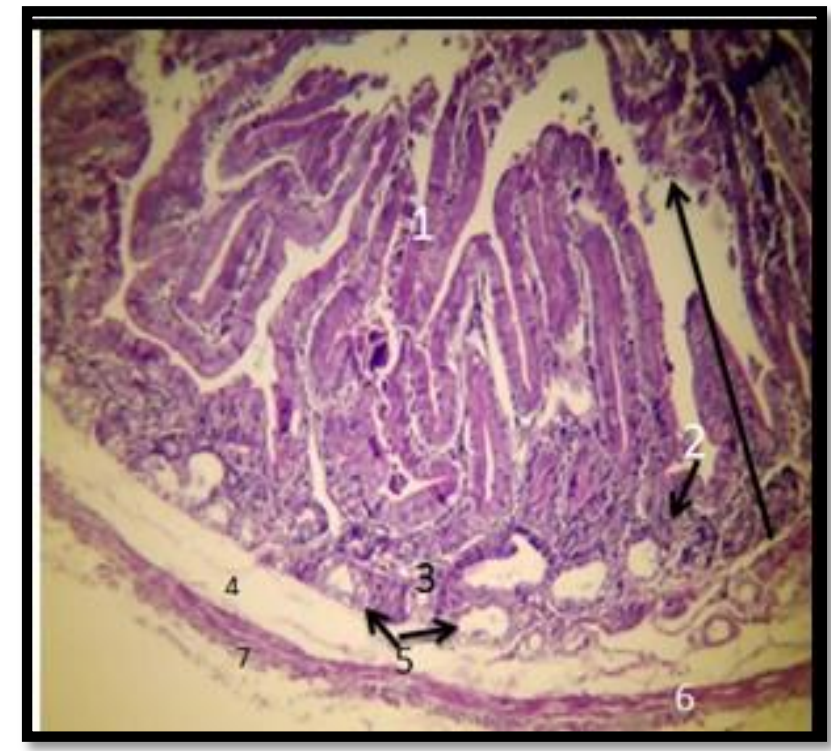

Figure 2 - The duodenum of the rabbit showing mucosa, contain villi (1) gland (crypt) of Liebrkuhn (2) muscolaris mucosa (3) ,sub mucosa (4), Brunner's gland(5) . muscularis (6) serosa(7). H\&E.100X

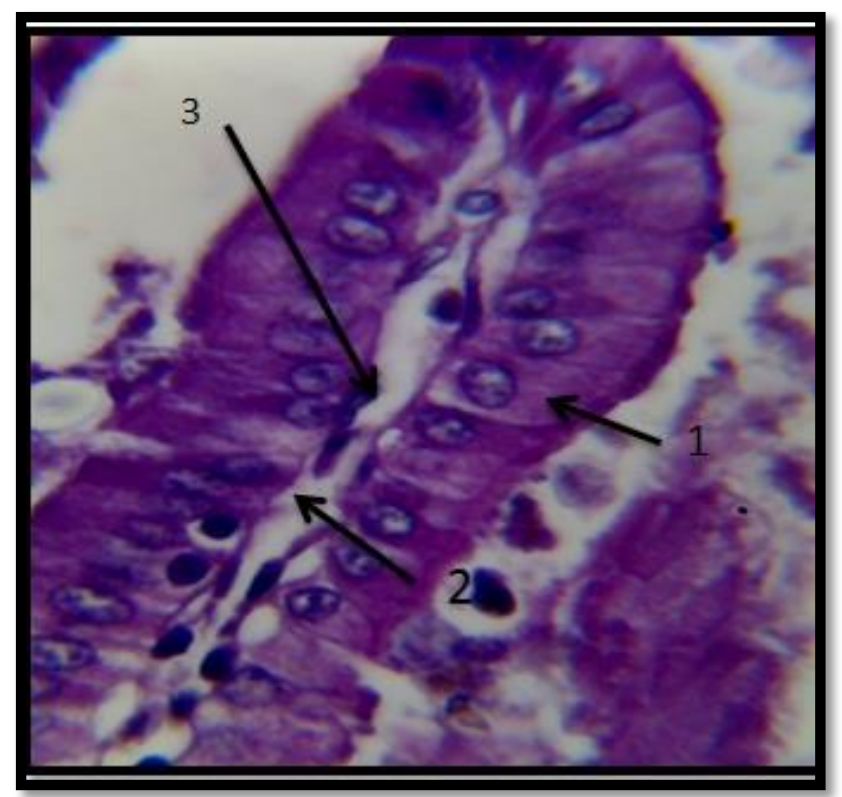

Figure 4 - The villi of the rabbit in doudenum consist of enterocytes (1), goblet cells (2), (lacteal) (3) of villi consist of loose connective tissue H\&E.100X 


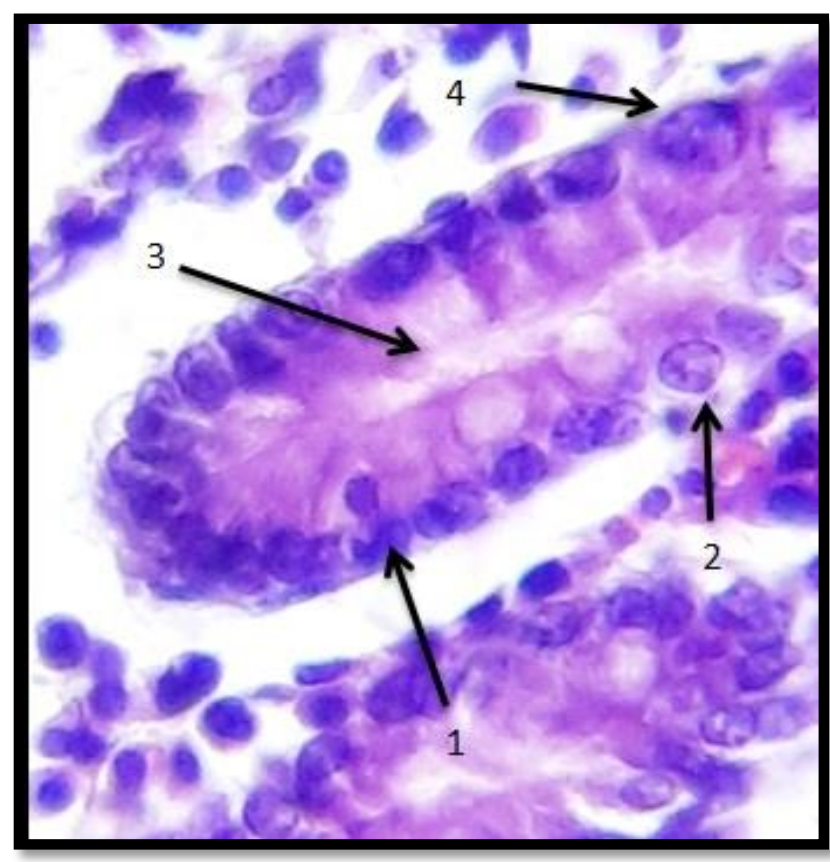

Figure 5- The glands (crypt) of liebrkuhn in the sheep showing (1) goblet cell, (2) columner cells, (3) leumn.(4) Paneth cells H\&E400x

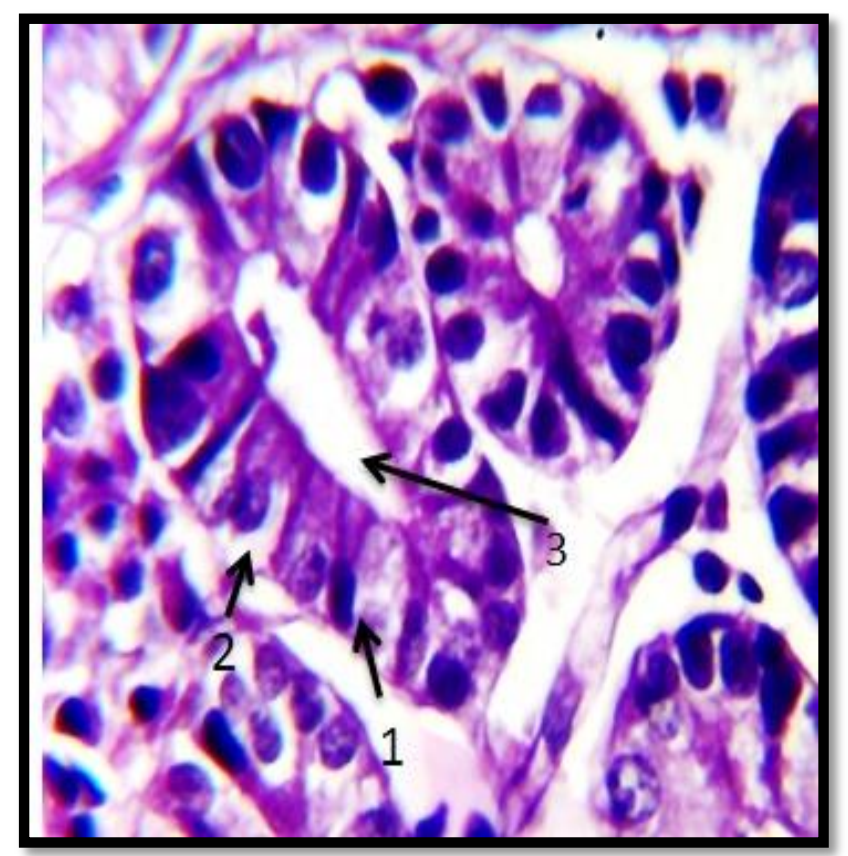

Figure 6 - The glands (crypt) of liebrkuhn in the rabbit showing (1) goblet cell, (2) columner cell, (3) leumn.(4) Paneth cells H\&E400

\section{Histomorphometeric study}

The thickness of sheep mucosa layer in the duodenum $(2146.31 \pm 158.24)$ significantly $(P<0.05)$ large in comparison to the duodenum of the rabbits where the value found were $846.84 \pm 55.03$ (Table 1). The villi height of sheep in the duodenum $(951.85 \pm 263.88)$ significantly $(P<0.05)$ large in comparison to the duodenum sections of rabbit small intestine where the values found were $566.90 \pm 127.8$ and $510.90 \pm 78.87$ (Table 1) respectively. The thickness of sheep submucosa layer in the duodenum $(228.61 \pm 54.77)$, significantly $(P<0.05)$ large comparison to sections the duodenum of the rabbits where the values found was $58.32 \pm 16.49$, respectively (Table 1 ). The thickness of sheep muscularis layer in the duodenum 264.22 \pm 101.37 , significantly $(P<0.05)$ was large in comparison to the same section of the rabbits where the values found was $69.99 \pm 29.99$ respectively. There were non- significant $(P>0.05)$ differences between the thickness of the serosa in sheep and rabbit in the duodenum (Table 1). In this respect, Mandir et al. (2005) consider that increase in thickness of intestinal epithelial tissue as well as the development of the gut itself can occur during three main mechanisms, that are elevation of cell production from the intestinal crypts, raise in number of crypt (by crypt fission) or by altered apoptosis. The thickness of the mucosa in rabbit duodenum $(846.84 \pm 55.03)$ and this result disagree with study Tomaszewska et al. (2014), which observed in guinea pigs female mucosa thickness of duodenum was (488.3 \pm 99.81 ), this difference might be related to the nature of the nutrition intake of the animals. Alves et al. (2004) reported that measurements of villi height give an indication of the likely maturity and functional capacity of enterocytes Villi height was in the mucosa duodenum of rabbit was $566.90 \pm 127.81$ and this result accordance with study of Yu and Chiou (1997) which was their result $(543 \pm 15)$ in rabbit. As wall this result disagrees with Mohammadpour (2011) observed villi high of guinea pig in mucosa duodenum was $785.00 \pm 87.67$, this difference might be related due vary in species.

Table 1 - Mean thickness of mucosa, submucosa, muscularis, and serosa in Duodenum of the small intestine of the sheep and rabbit $n=10$

\begin{tabular}{|c|c|c|c|c|c|c|c|c|c|c|}
\hline \multirow{2}{*}{$\begin{array}{c}\text { Organ } \\
\text { Small } \\
\text { intestine }\end{array}$} & \multicolumn{2}{|c|}{ Mucosa } & \multicolumn{2}{|c|}{ Sub mucosa } & \multicolumn{2}{|c|}{ Musclaris } & \multicolumn{2}{|c|}{ Serosa } & \multicolumn{2}{|c|}{ Height villi } \\
\hline & Sheep & Rabbit & Sheep & Rabbit & Sheep & Rabbit & Sheep & Rabbit & Sheep & Rabbit \\
\hline Duodenum & $\begin{array}{l}2146.31^{\mathrm{a}} \\
\pm 158.24\end{array}$ & $\begin{array}{l}846.84^{b} \\
\pm 55.03\end{array}$ & $\begin{array}{l}228.61^{\mathrm{a}} \\
\pm 54.77\end{array}$ & $\begin{array}{r}58.32^{b} \\
\pm 16.49\end{array}$ & $\begin{array}{l}264.22^{a} \\
\pm 101.37\end{array}$ & $\begin{array}{r}69.99 \mathrm{~b} \\
\pm 29.09\end{array}$ & $\begin{array}{r}2013.37^{a} \\
\pm 5850.70\end{array}$ & $\begin{array}{r}46.66^{a} \\
\pm 21.99\end{array}$ & $\begin{array}{r}951.85^{\mathrm{a}} \\
\pm 268.88\end{array}$ & $\begin{array}{l}566.90^{b} \\
\pm 127.81\end{array}$ \\
\hline
\end{tabular}

\section{Histochemical study}

In both animals, the columnar cells gave a weakly reaction with PAS (Figure 7) and this may be indicate a lack of mucus secretion by these cells and this finding consistent with study of Andleeb et al. (2009). Goblet cells in sheep and rabbits, these cells gave strong reaction with PAS and this is evidence of neutral mucus in duodenum. Moreover, Kadadi (2012) stated that duodenal goblet cells in sheep stained with magenta indicating presence of PAS positive material in their secretion. Jawad et al. (2019) stated that crypts of Lieberkuhn in the tunica mucosa of the duodenum in rabbits positive reaction with PAS. In addition, Brunner's glands of the sub mucosa layer in gave a strong reaction with PAS in sheep duodenum (Figure 7), while in the rabbits were Brunner's glands mixed gland (serous cells a weak reaction with 
PAS and mucous cells moderate reaction with PAS (Figures 8 and 9). Kadadi (2012) which reported that Brunner's glands in sheep showed positive reaction with PAS. However, Sub-mucosal glands are varying with species and there are three types of acini (mucus, serous and mixed). In previous studies; Mohammadpour (2011) and Krause, (2000) observed that Brunner's glands in Guiana pig and moose they mucos acina only. The studies uses different techniques depend on species, duodenal sub-mucosal glands were reported to contain neutral or acidic mucin glycoproteins or the combination of both types of mucin (Takehana et al., 1991; Krause, 2000). Andleeb et al. (2009) reported that Brunner's glands in Gaddi goat gave strong reaction with PAS and this is evidence of the presence of neutral carbohydrates.

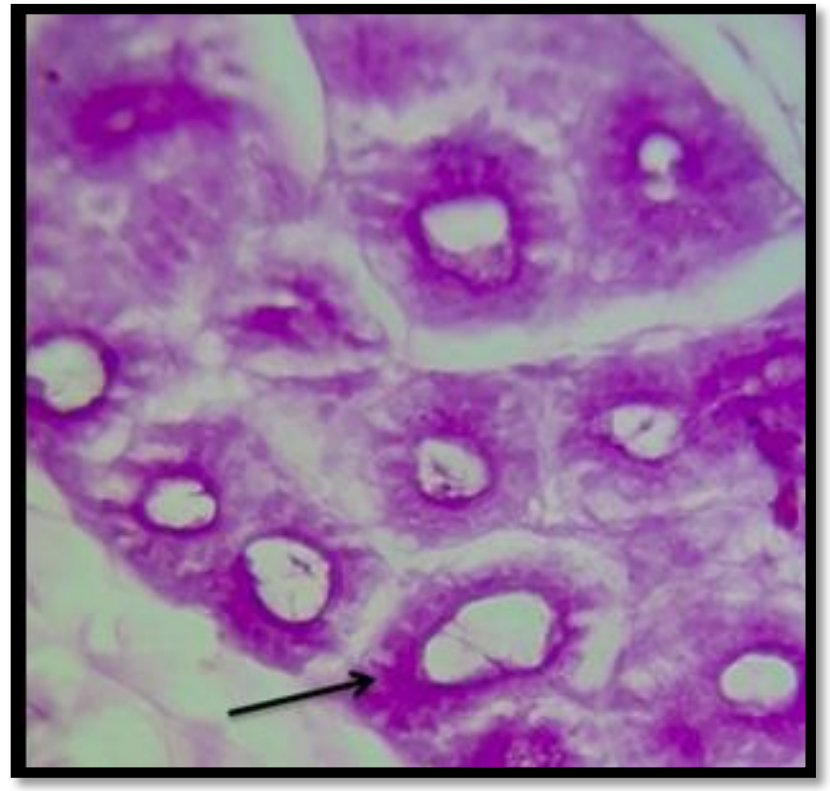

Figure 7 - The Brunner's gland of the sheep duodenum showing (mucous acini) gave strong reaction with PAS.400X

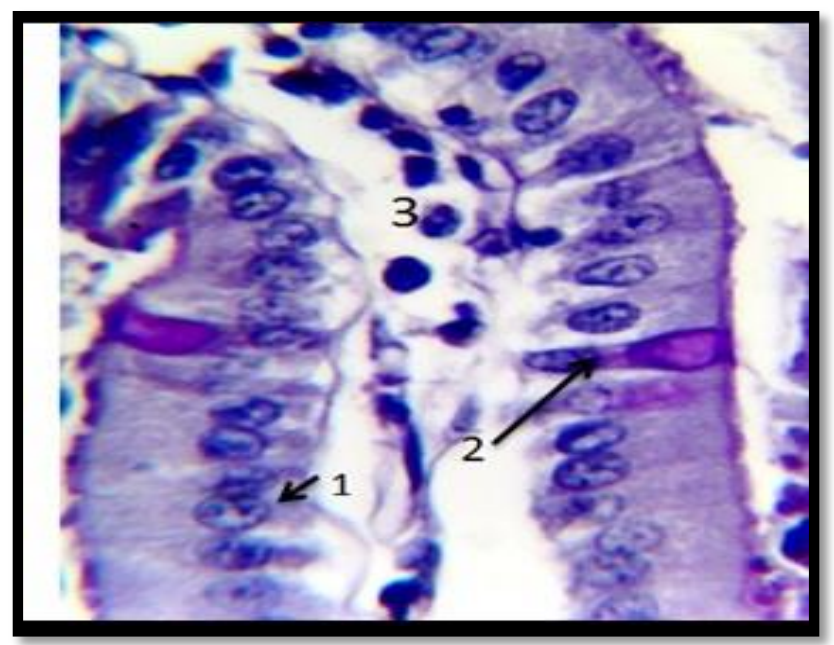

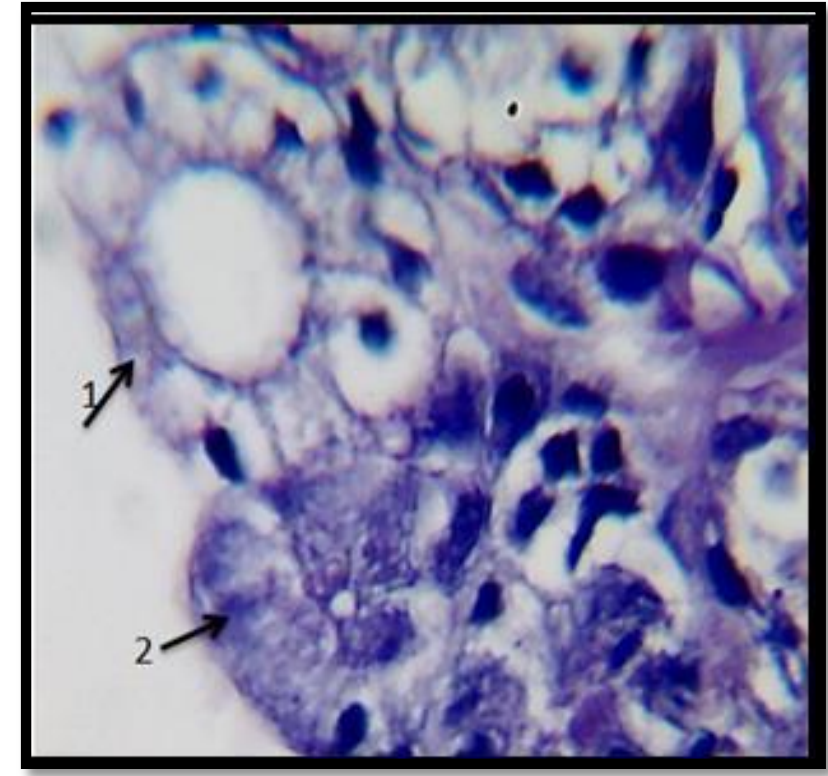

Figure 8 - The Brunner's gland of the rabbit duodenum showing (1) serous cells gave weakly reaction with PAS. (2) mucous cells moderate reaction with PAS.400X

Figure 9 - The villi of the rabbit doudenum consist of enterocytes ( 1) and goblet cells (2) showing strong reaction with PAS . (lacteal) (3) of villi consist of loose connective tissue.PAS.400x

\section{CONCLUSION}

These findings indicated similarities and some different between herbivores species. In sheep and rabbits, the duodenum is composed of four layers: mucosa, submucosa, muscular, and serosa. In both animals, in duodenum, the submucosa is occupied by Brunner's glands. Brunner's glands are vary in secretory unit acinai in rabbit serous and mucous acini while in sheep the mucus acini. There is significant difference in thickness of layers between sheep and rabbits. Mucosa, sub mucosa and muscularis layers in sheep showed more thickness than in rabbits, but there is non-significant differences between the thickness of the serosa in sheep and rabbit in the duodenum. On the other hand, the columnar cells showed a weakly reaction with PAS, but goblet cells in sheep and rabbits shown strong reaction with Periodic acid Schiff stains (PAS). While the Brunner's glands were strong reaction with PAS in sheep submucosa. 


\section{DECLARATIONS}

\section{Acknowledgements}

The authors thank the head of the Biology Department at the College of Sciences for his cooperation.

\section{Conflict of interest}

The authors declare no conflict of interest.

\section{Authors' contribution}

All authors contributed equally to this research work. All authors read and approved the final manuscript.

\section{REFERENCES}

AL-Baghdady EF, AL-Mehanna NH, and Kadhim KH (2012). The distribution of the goblet cells, paneth cells and brunner's glands in duodenum of adult one Humped Camels (Camelus dromedarius). Al-Qadisiyah Journal of Veterinary Medicine Sciences, 11(2): 46-52. Google Scholar ; DOI: https://doi.org/10.29079/vol11iss2art190

Al-Shamary ER, Jarad AS, Taher IA, AI-Saffar FJ, and Naji WA (2017). Some histo-morphometric and histochemical comparsion aspect of the duodenum in Collard Dove (Frivaldszky), Ruddy Shelduck (Pallas) and Owl (Otus Scors brucei) in south Iraq. Journal of Entomology and Zoology Studies, 5(6): 923-928. Google Scholar ; Link

Al-Rawi KM, and Khalaf Allah AM (2000). Design and Analysis of Agricultural Experiments. University of Mosul. Ministry of Higher Education and Scientific Research. Dar AI Kuttab for printing and publishing. Mosul. Iraq. Google Scholar

Alves A, Pinheiro V, Mourão JL, Pires I, Oliveira J, and Gama A. (2004). Measurement of rabbit's intestinal villus: Preliminary comparison of two methods. In Proceedings of the $8^{\text {th }}$ World Rabbit Congress, Puebla, Mexico, pp. 422-426. Google Scholar ; Link

Andleeb RR, Bhardwaj RL, and Sharma KB (2009). Histochemical studies on the small intestine of Gaddi goat. Indian Journal of Animal Physiology, 2: 75-78. Google Scholar

Blackshaw JK, Fenwick DC, Beattie AW, and Allan DJ (1988). The behavior of chickens, mice and rats during euthanasia with chloroform, carbon dioxide and ether. Laboratory Animals, 22(1): 67-75. Google Scholar ; Dol: https://doi.org/10.1258\%2F002367788780746674

Calamar CD, Patruica S, Dumitrescu G, Bura M, Dunea IB, and Nicula M (2014). Morpho-histological study of the digestive tract and the annex glands of Chinchilla laniger. Scientific Papers Animal Science and Biotechnologies, 47(1): 269-274. Google Scholar ; Link

Crowley EJ, King JM, Wilkinson T, Worgan HJ, Huson KM, Rose MT, and McEwan NR (2017). Comparison of the microbial population in rabbits and guinea pigs by next generation sequencing. PloS one, 12(2): e0165779. Google Scholar ; DOI: https://doi.org/10.1371/journal.pone.0165779

Cunningham JG, and Klein BG (2007).Textbook of Veterinary Physiology, $4^{\text {th }}$ ed: WB Saunders/Elsevier Science, Philadelphia, USA. Pp. 720. Google Scholar ; Link

Elnasharty MA, Abou-Ghanema II, Sayed-Ahmed A, and Elnour AA. (2013). Mucosal-Submucosal Changes in Rabbit Duodenum during Development. World Academy of Science, Engineering and Technology, I :7-14. Google Scholar ; Link

Emel E, Leven E, Aseman O, and Aytul K (2010). Histomorphology of the Brunner gland in the Angora rabbit. Journal of Animal and Veterinary Advances, 9(5): 887-891. Google Scholar ; DOI: http://dx.doi.org/10.3923/javaa.2010.887.891

Ergun E, Ergun L, Asti RN, and Kurum A (2003). Light and electron microscopic morphology of Paneth cells in the sheep small intestine. Revue de Médecine Vétérinaire, 154(5): 351-355. Google Scholar ; Link

Hassan SA, and Moussa EA (2015). Light and scanning electron microscopy of the small intestine of goat (Capra hircus). Journal of Cell and Animal Biology, 9(1): 1-8. Google Scholar ; Link

Gadelha-Alves R, Rozensztranch AMS, and Rocha-Barbosa 0 (2008). Comparative intestinal histomorphology of five species of Phyllostomid Bats (Phyllostomidae, Microchiroptera): ecomorphological relations with alimentary habits. International Journal of Morphology, 26(3): 591-602. Google Scholar ; DOI: http://dx.doi.org/10.4067/S0717-95022008000300014

Galigher AE, and Kozloff EN (1964). Essentials of practical microtechnique.1 ${ }^{\text {st }}$ ed. lea and febiger. Philadelphia, pp. 40-45. Google Scholar

Jawad I, Kadhim KH, Kadhim DM, and Sadiq DH. (2019). A comparative histomorphological and histochemical study of the goblet cells and brunner's glands in the duodenum of Rabbits and Rats. Research Journal of Pharmacy and Technology, 12(5): 2421-2424. Google Scholar ; DOI: https://doi.org/10.5958/0974-360X.2019.00406.2

Kingston-Smith AH, Marshall AH, and Moorby J M (2012). Breeding for genetic improvement of forage plants in relation to increasing animal production with reduced environmental footprint. Animal, 7(S1): $79-88 . \quad$ Google Scholar ; DOI: https://doi.org/10.1017/S1751731112000961

Kadadi SP (2012). Histology and histochemical study of human brunner's glands in comparison with a few mammals, phD. Thesis, Rajiv Gandhi University Health Sciences, Karnataka, Bangalore, pp. 155. Google Scholar ; Link

Korkmaz D, and Kum S (2016). Histological study of the small intestine of the dromedary. Journal of Camel Practice and Research. 23(1): 111-116. Google Scholar ; DOI: http://dx.doi.org/10.5958/2277-8934.2016.00018.7

Krause WJ (2000). Brunner's glands: A structural, histochemical and pathological profile. Progress in Histochemistry and Cytochemistry, 35(4): 255-367. Google Scholar ; DOI: https://doi.org/10.1016/S0079-6336(00)80006-6

Kumar PA, Kumar PAW, Singh GU, Poonia AM, and Parkash T (2015). Histoarchitecture and histochemistry of the ileum of sheep (Ovis Aries). Haryana Veterinarian, 54(1): 50-52. Google Scholar ; Link

Mandir N, FitzGerald AJ, and Goodlad RA (2005). Differences in the effects of age on intestinal proliferation, crypt fission and apoptosis on the small intestine and the colon of the rat. International Journal of Experimental Pathology, 86(2): 125-130. Google Scholar ; DOI: https://doi.org/10.1111/j.0959-9673.2005.00422.x

Mohammadpour AA (2011). Morphological and histochemical study of guinea pig duodenal submucosal glands. Bulgarian Journal of Veterinary Medicine, 14(4): 201-208. Google Scholar ; Link

Mohamed AMA, Taha AM, and Ali AM (2019). Morphology of Intestinal Goblet Cells of The Dromedary (Camelus dromedarius). Anatomy Journal of Africa, 8(1): 1379-1384. Google Scholar ; Link

Lesson TS, Lesson, C. R., and Paparo, A. A. (1988). Text/atlas of histology. W. R. Saunders Co., Philadelphia, London, Toronto. pp. 434-456. Google Scholar 
Luca F, Perry GH, and Di Rienzo A. (2010). Evolutionary adaptations to dietary changes. Annual Review of Nutrition, 30: 291-314. Google Scholar ; DOI: https://doi.org/10.1146/annurev-nutr-080508-141048

Luna LG (1968). Manual of Histologic Staining Methods of the Armed Forces Institute of Pathology.3rd ed., McGraw Hill Book Co., New York, pp. 368. Google Scholar

Parveen K, Pawan K, Gurdial S, and Amit P (2013). Histological architecture and histochemistry of duodenum of the sheep (Ovis aries). Indian Journal of Veterinary Anatomy, 25(1): 30-32. Google Scholar ; Link

Saeed OA, Sazili AQ, Akit H, Alomon AR, Samsudin AAB (2018). Effect of corn supplementation on purine derivatives and rumen fermentation in sheep fed PKC and urea-treated rice straw. Tropical Animal Health and Production, 50: 1859-1864. Google Scholar ; DOI: https://doi.org/10.1007/s11250-018-1636-1

Salama WA, Refaie AM, Amin HF, and Abdel-Mawla LF. (2019). Use of untreated and autoclave-treated wheat germ meal in growing Rabbit diets. World Veterinary Journal, 9(3): 192-200. Google Scholar ; Link

Stinson ALW and Calhoun ML (1993). Text Book of Veterinary Histology. $4^{\text {th }}$ ed., Lea and Febiger, Philadelphia.

Takehana K, Abe M, Iwasa K, Hiraga T, and Miyata H (1991). Carbohydrate histochemistry of bovine duodenal glands. Journal of Veterinary Medical Science, 53(4): 699-706. Google Scholar ; DOI: https://doi.org/10.1292/jvms.53.699

Tomaszewska E, Dobrowolski P, Puzio I, Prost L, Kurlak P, Sawczuk P, and Kostro K (2014). Acrylamide-induced prenatal programming of intestine structure in guinea pig. Journal of Physiology and Pharmacology, 65(1): 107-15. Google Scholar ; PMID: 24622835.

Yu B, and Chiou PW (1997). The morphological changes of intestinal mucosa in growing rabbits. Laboratory Animals, 31(3): 254-263. Google Scholar ; DOI: https://doi.org/10.1258\%2F002367797780596301 